\title{
Pengembangan Sistem Monitoring Langkah Kaki Dengan Sensor MPU6050 Untuk Menghitung Jumlah Penurunan Berat Badan Berbasis Android
}

\author{
Sabrina Nurul Ubay ${ }^{* 1}$, Wahyu Andhyka Kusuma ${ }^{2}$, Zamah Sari ${ }^{3}$ \\ 1,2,3 Teknik Informatika/Universitas Muhammadiyah Malang \\ sabrinanurulubay22@gmail.com ${ }^{* 1}$, kusuma.wahyu.a@gmail.com² ${ }^{2}$,zamahsari@umm.ac.id ${ }^{3}$
}

\begin{abstract}
Abstrak
Jalan kaki memiliki banyak manfaat, dan salah satunya adalah untuk menurunkan berat badan. Dalam usaha untuk menurunkan berat badan diperlukan adanya pembakaran kalori. Untuk mengetahui hasil pembakaran kalori diperlukan suatu alat yaitu Daily Fitness Activity yang gunanya untuk memonitoring pembakaran kalori dan penurunan berat badan dengan penghitungan menggunakan suatu rumus yang melibatkan jumlah langkah kaki, waktu, serta berat badan pengguna. Untuk mendapatkan jumlah langkah kaki dibutuhkan suatu alat yaitu gyroscope dari sensor MPU6050. Sensor tersebut berperan sebagai monitoring langkah kaki karena berfungsi untuk mengukur dan menentukan orientasi suatu benda berdasarkan pada ketetapan momentum sudut.
\end{abstract}

Kata kunci: Gyroscope, Kalori, Daily Fitness Activity

\section{Abstract}

Walking has many benefits, and one of them is to lose weight. In an effort to lose weight, it needs calorie burning. To find out the calorie burning results required a tool that is Daily Fitness Activity is useful for monitoring calorie burning and weight loss by calculation using a formula that involves the number of footsteps, time, and weight of the user. To get the required number of foot steps a tool is a gyroscope of the MPU6050 sensor. The sensor acts as foot step monitoring because it serves to measure and determine the orientation of an object based on the determination of angular momentum.

Keywords: Gyroscope, Calories, Daily Fitness Activity

\section{Pendahuluan}

Semakin berkembangnya ilmu pengetahuan dan teknologi, semakin banyak pula inovasiinovasi baru yang muncul dalam berbagai ilmu. Cabang ilmu olahraga merupakan salah satu contoh yang terpengaruh oleh adanya perkembangan teknologi. Dan olahraga yang dapat dilakukan sehari-hari dengan mudah yaitu olahraga jalan kaki.

Menurut Iknoian, berjalan kaki adalah serangkaian gerak langkah lurus ke depan. Berapa pun kecepatan dan jarak yang ditempuh, tetap berdiri tegak adalah kuncinya [1]. Olahraga jalan kaki tak sekedar dapat dilakukan oleh siapa saja, berjalan kaki juga menjadi latihan yang paling nyaman karena merupakan aktivitas harian. Jalan kaki sendiri memiliki banyak manfaat, dan salah satunya adalah untuk menurunkan berat badan. Dalam usaha untuk menurunkan berat badan diperlukan adanya pembakaran kalori.

Penurunan berat badan diartikan sebagai penurunan massa dan lemak tubuh [2]. Saat berolahraga, penting bagi kita untuk mengetahui apa hasil yang telah kita capai setelah berolahraga. Seperti berapa jumlah langkah yang didapatkan, jarak yang ditempuh, waktu yang dihabiskan saat berolahraga dan kalori yang terbakar. Sebuah review menunjukkan bahwa program penurunan berat badan dengan menghitung kalori menghasilkan rata-rata sekitar $3,3 \mathrm{~kg}$ turunnya berat badan dibandingkan pada beberapa orang yang tidak menghitungnya [3]. Dikutip dari Healthy Food Star, tolak ukur untuk menghitung pembakaran kalori menggunakan jarak. Dalam menempuh 1,6 kilometer jarak saat berjalan, ada 100 kalori yang terbakar. Jarak tersebut biasanya ditempuh dengan 2000 langkah. Untuk mendapatkan 1 pon atau 0,45 kilogram yang terbakar, terhitung harus menghancurkan 3500 kalori. Jika ingin menurunkan 1 pon per minggu, maka harus menghabiskan 500 kalori per hari [4]. 
Berbeda dengan kutipan Healthy Food Star, menurut Aris Dwi Fitriyanti [5] untuk menghitung pembakaran kalori tolak ukur yang digunakan adalah kecepatan dikarenakan meskipun jarak yang ditempuh sama tetapi kecepatannya berbeda, maka dapat dihasilkan pembakaran kalori yang berbeda. Kecepatan sendiri didapatkan dari hasil perhitungan jumlah langkah kaki dibagi waktu (menit).

Pada penelitian Ayu (2016) telah dibuat rancang bangun sistem monitoring langkah kaki dengan sensor MPU6050 berbasis Android [6] yaitu untuk menentukan jumlah langkah kaki dan jarak yang telah ditempuh dengan sensor gyroscope menggunakan perbandingan nilai batas (Threshold) pada data sumbu $X$ yang kemudian sensor akan menampilkan data berupa jumlah langkah kaki dan jarak dengan melalui aplikasi Android.

Oleh karena itu, pada penelitian ini penulis mengembangkan dari penelitian sebelumnya dengan meningkatkan akurasi sistem monitoring langkah kaki dan menambahkan fitur berupa waktu dan fitur yang dapat menghitung jumlah pembakaran kalori beserta jumlah penurunan berat badan berdasarkan pada jumlah langkah kaki yang didapat. Penelitian pengembangan sistem monitoring langkah kaki dengan sensor MPU6050 untuk menghitung jumlah penurunan berat badan berbasis Android ini diharapkan nantinya dapat membuat setiap orang untuk lebih mengontrol olahraganya karena sistem ini dapat memantau jumlah kalori yang terbakar beserta jumlah berat badan yang berkurang yang dapat dilihat melalui handphone Android.

\section{Metode Penelitian}

\subsection{Deskripsi Sistem}

Pada tugas akhir ini akan dikembangkan aplikasi untuk menghitung jumlah penurunan berat badan berdasarkan dari jumlah langkah kaki yang dimonitoring menggunakan aplikasi Android. Aplikasi Android ini diberi nama Daily Fitness Activity. Alat ini dirancang untuk memudahkan user untuk mengontrol aktifitas berjalan sehari-hari karena sistem ini dapat memantau jumlah langkah, jarak, waktu, jumlah kalori yang terbakar beserta jumlah berat badan yang berkurang yang dapat dilihat melalui handphone Android. Alat penghitung penurunan berat badan ini diletakkan pada bagian paha, seperti pada Gambar 1.

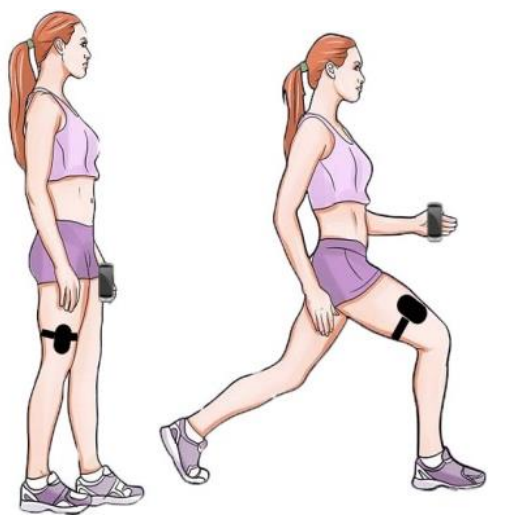

Gambar 1. Posisi Penggunaan Alat [6]

Ketika Bluetooth sudah saling terkoneksi, sensor akan membaca data hasil dari langkah kaki. Kemudian data yang dimaksud adalah berupa nilai sudut dari sumbu X, Y, dan Z. Nilai sudut tersebut dikonversikan dalam bentuk grafik gelombang sinus agar mudah menentukan threshold atas dan bawah pada sudut yang membentuk nilai gelombang. Dari ketiga nilai percepatan tersebut diambil salah satu sumbu kemudian ditentukan nilai threshold untuk batas atas dan batas bawah atau bisa juga disebut threshold above dan threshold below [7]. Pada sistem ini, diambil nilai salah sudut yang digunakan untuk mendeteksi langkah kaki dan perhitungan jarak yaitu sumbu X. Saat melakukan percobaan berjalan, sumbu X membaca data dari pergerakan kaki, jika nilai batas (Threshold) atas dan bawah sesuai dengan threshold yang ditentukan, maka terdeteksilah suatu langkah [6].

Setelah mengaktifkan Bluetooth, terlebih dahulu menginputkan berat badan. Dalam berjalan pola manusia saat melangkah pada dasarnya terdapat dua fase, fase stance dan fase swing [8]. Kemudian saat berjalan, hasil langkah dikalikan dengan lebar rata-rata kaki saat berjalan untuk menghitung jarak. Besar langkah kaki sendiri secara rata-rata adalah $78 \mathrm{~cm}$ atau

REPOSITOR, Vol. 2, No. 1, Januari 2020: 107-112 
diasumsikan satu langkah manusia sepanjang 0.78m [9].. Kemudian untuk menghitung jumlah pembakaran kalori dibutuhkan jumlah langkah, waktu yang ditempuh, dan berat badan awal.

Untuk penghitungan penurunan berat badan yaitu hasil pembakaran kalori dikali 0,000128 (3500 kalori $=0,45$ kilogram). Lalu semua data tersebut di kirimkan ke smartphone Android melalui transmisi Bluetooth berupa hasil jumlah langkah kaki, jarak, waktu, jumlah pembakaran kalori dan jumlah penurunan berat badan yang ditampilkan di aplikasi Android. Gambar 2 berikut ini adalah alur sistem cara kerja alat secara umum.

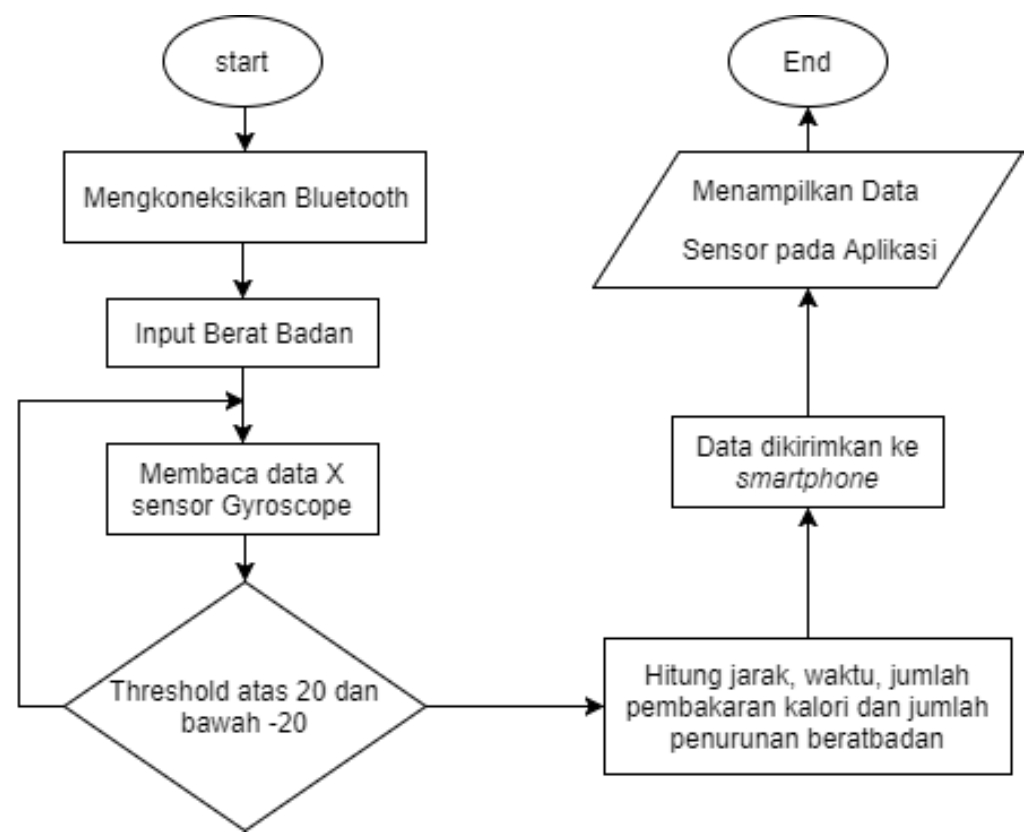

Gambar 2. Proses Cara Kerja Alat

\subsection{Proses Sistem Perangkat Keras}

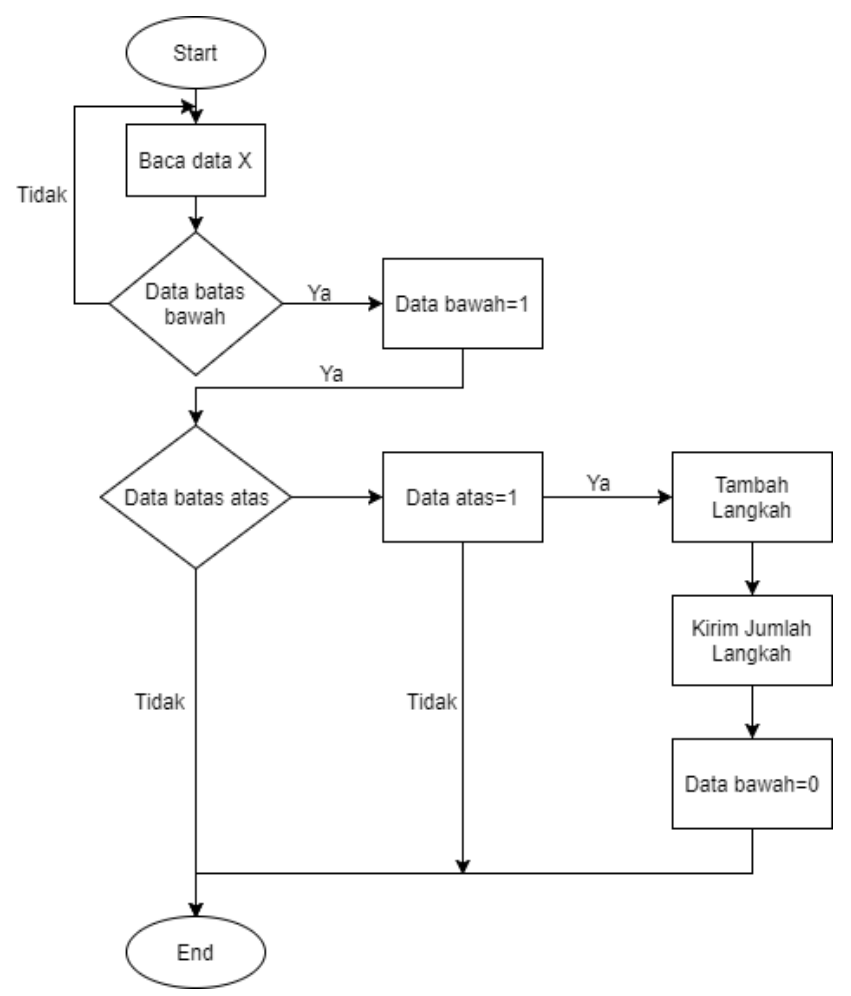

Gambar 3. Diagram Alur Sistem 
Gambar 3 menunjukkan deteksi langkah kaki menggunakan sensor MPU6050 meliputi accelerometer serta Gyroscope. Faktor gyroscope memiliki peranan yang sangat penting dalam hal mempertahankan keseimbangan suatu benda yang dapat menentukan kemiringan pada sumbu X, Y, dan Z [10]. dilakukan pada pendeteksian suatu gelombang yang diambil dari batas nilai atas dan batas nilai bawah (Threshold) pada sumbu $X$. Jika nilai batas atas dan bawah perbandingannya sesuai dengan threshold yang telah ditentukan, maka terdeteksi lah suatu langkah kaki.

\subsection{Proses Sistem Perangkat Lunak}

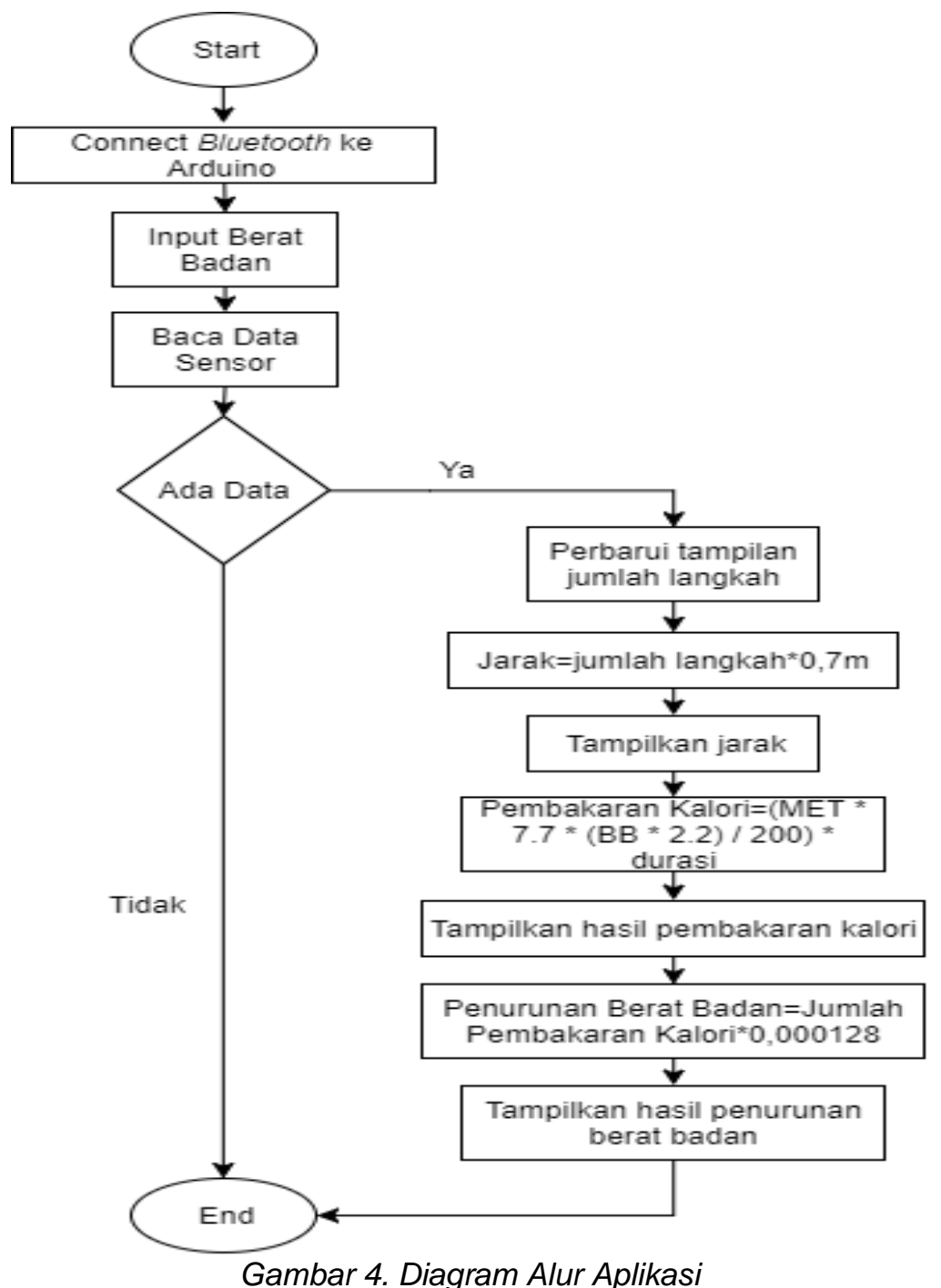

Gambar 4 diatas menunjukkan bagaimana alur dari system tersebut. Sebelum memulai monitoring, Android harus terkoneksi dulu dengan Arduino dengan cara connect Bluetooth. Kemudian pengguna menginputkan jumlah berat badan. Sensor mulai membaca data, jika ada data deteksi langkah kaki, maka aplikasi akan memperbaharui tampilan jumlah langkah dan melakukan perhitungan jarak dan jumlah pembakaran kalori yang kemudian melakukan perhitungan jumlah penurunan berat badan dari hasil perhitungan jumlah pembakaran kalori yang nantinya akan ditampilkan di aplikasi Android.

\section{Hasil Penelitian dan Pembahasan}

Hasil penelitian ialah didapatkan penurunan berat badan pada aplikasi sesuai dengan penurunan berat badan sebelum menggunakan perangkat dan setelah menggunakan perangkat.

REPOSITOR, Vol. 2, No. 1, Januari 2020: 107-112 


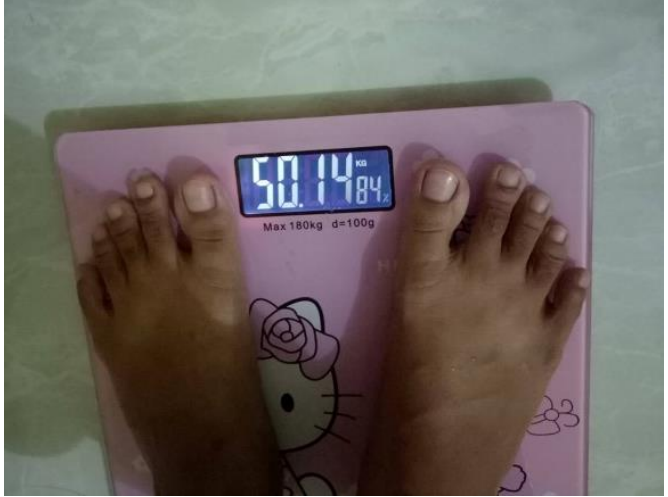

Gambar 5. Berat Badan Pengguna Sebelum Melakukan Pengujian

Sebelum menggunakan perangkat, dilakukan pengukuran berat badan untuk mengetahui perbedaan berat badan sebelum dan sesudah menggunakan perangkat seperti pada Gambar 6 . Tujuan dari mengetahui perbedaannya adalah untuk membandingkan selisih dari hasil berat badan sebelum dan sesudah menggunakan perangkat apakah sesuai dengan hasil perhitungan penurunan berat badan pada aplikasi.

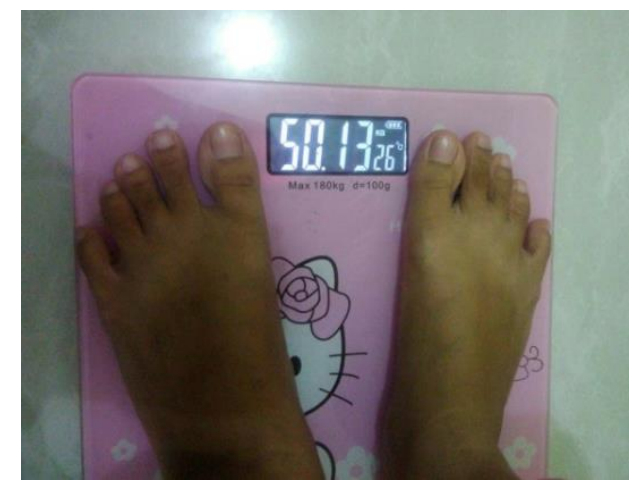

Gambar 6. Berat Badan Pengguna Setelah Melakukan Pengujian

Setelah menggunakan perangkat, dilakukan pengukuran berat badan kembali untuk mengetahui apakah ada perubahan pada berat badan pengguna, seperti pada Gambar 6 . Setelah dilakukan pengukuran berat badan sebelum dan sesudah menggunakan perangkat, hasil dari kedua pengukuran tersebut dihitung selisihnya dengan menggunakan Persamaan 1 dan ditunjukkan pada Gambar 7.

$$
\begin{gathered}
\text { Selisih = Berat Badan Sebelum }- \text { Berat Badan Sesudah } \\
=50.14-50.13 \\
=0.01
\end{gathered}
$$

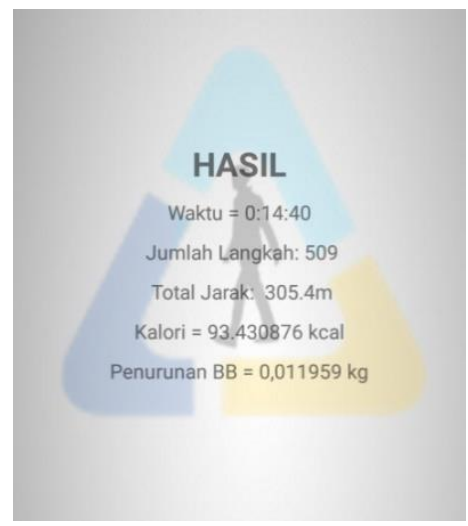

Gambar 7. Hasil Perhitungan Aplikasi 
Selisih dari hasil pengukuran berat badan sebelum dan sesudah menggunakan perangkat sesuai dengan hasil penurunan berat badan pada aplikasi yaitu sebesar $0.01 \mathrm{~kg}$. Hasil validasi perhitungan sistem menggunakan perhitungan manual pada Persamaan 2 dan Persamaan 3.

a. Perhitungan Pembakaran Kalori

$$
\begin{gathered}
\mathrm{EC}=(\mathrm{MET} * 7.7 *(\mathrm{BB} * 2.2) / 200) * \text { durasi } \\
=\left(1.5^{*} 7.7^{*}\left(50.14^{*} 2.2\right) / 200\right){ }^{*}(880 / 60) \\
=\left(1.5^{*} 7.7^{*} 110.308 / 200\right){ }^{*} 14.666667 \\
=6.370287^{*} 14.666667 \\
=93.430876
\end{gathered}
$$

b. Perhitungan Penurunan Berat Badan

$$
\begin{gathered}
\mathrm{PBB}=\mathrm{EC} * 0.000128 \\
=93.430876 * 0.000128 \\
=0.011959
\end{gathered}
$$

\section{Kesimpulan}

Dengan adanya alat berikut, peneliti bermaksud memudahkan seseorang untuk dapat mengetahui dan melakukan controlling hasil olaharaganya. Data hasil olahraga ditampilkan pada aplikasi Android dimana dalam aplikasi Android menampilkan hasil dari jumlah langkah kaki, jarak tempuh, waktu yang dilalui, hasil pembakaran kalori serta hasil penurunan berat badan. Dari hasil pengujian yang dilakukan, didapati hasil yang sesuai bedasarkan pengujian berat badan menggunakan perangkat dan tidak menggunakan perangkat dan divalidasi menggunakan perhitungan rumus secara manual.

\section{Referensi}

[1] Widya, Ardyan Putra., Ivano, Raymond Avandi. Survei TIngkat Kebugaran Jasmani Masyarakat Usia di Atas 40 Tahun pada Anggota Arca Hash Club Kabupaten Madiun. Pendidikan Kepelatihan Olahraga Universitas Negeri Surabaya.

[2] DocDoc. "Apa itu Penurunan Berat Badan: Gejala, Penyebab, Diagnosis, dan Cara

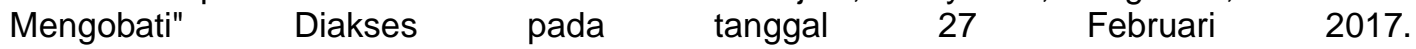
https://www/docdoc.com/id/info/condition/penurunan-berat-badan.

[3] John Willey. "Effect of behavioural techniques and delivery mode on effectiveness of weight management: systematic review, meta-analysis and meta-regression". Diakses pada tanggal 26 Februari 2017. https://www.ncbi.nlm.nih.gov/pubmed/24636238.

[4] CNN. "Turunkan Berat Badan dengan Berjalan Kaki". Diakses pada tanggal 4 Februari 2017. https://www.cnnindonesia.com/gaya-hidup/20160818115814-255-152171/turunkan-beratbadan-dengan-berjalan-kaki/.

[5] Dwi, Aris Fitriyanti. Aplikasi Penghitung Kalori Terbakar Saat Berolahraga Sepeda mengunakan Global Positioning System (GPS) Berbasis Android. Jurnal Teknologi Informasi Vol. 4 No. 2.

[6] Ayu, Diah Fitriani.(2016). Rancang Bangun Sistem Monitoring Langkah Kaki Dengan Sensor MPU6050 Berbasis Android.

[7] Taufik, Muhammad Yusuf.(2015). Membedakan Objek Menggunakan Metode Thresholding dan Fungsi Morfologi

[8] Dhesta, Suis Meinggariyad.(2012). Pemetaan Posisi dan Orientasi Arah Sistem Navigasi Personal Berbasis Prinsip Dead Reckoning.

[9] Candra, Aditya Alim.(2015). Aplikasi Penghitung Langkah (pedometer) Berbasis Android

[10] Putu, Giovanni. "Accelerometer dan Gyroscope". Diakses pada tanggal 3 Maret 2017. http://www.geyosoft.com/2013/accelerometer-dan-gyroscope 